\title{
THE EVOLUTION AND THE NEW FRONTIERS OF SOCIAL RESPONSIBILITY ACCOUNTING
}

\author{
Anna Wildowicz-Giegiel \\ University of Bialystok, Bialystok, Poland \\ E-mail: awildowicz@interia.pl
}

\begin{abstract}
It is required currently from enterpeneurs to run their business according to the principles of sustainable development. As a result the rapid growth for corporate social responsibility among business owners is commonly observed. They started noticing that being socially responsible can help improve financial results and competitiveness. In order to achieve these goals company involving in corporate social responsibility should disclose accurately and credibly information on the social and environmental effects to both external and internal stakeholders.

The research was aimed at indicating the limitations of traditional accounting and the benefits of integrated reporting. The research problem concerns the informative gap between data being reported in traditional financial reports and stakeholders' requirements which appears as a consequence of existing accounting procedures and traditional financial reporting frameworks. According to hypothesis adopted in this paper integrated reporting helps diminish the information gap. On the basis of the conducted analysis it has to be said that, integrated reporting as a communication tool enables the company to build social trust and serve as a differentiator in a competitive environment. That is the reason why, despite the lack of a globally accepted integrated reporting framework, companies are more prone to prepare reports voluntarily.
\end{abstract}

Key words: corporate social responsibility, social responsibility accounting, intangibles, integrated reporting.

\section{Introduction}

The idea of corporate social responsibility (CSR) is gaining more importance in a global economy. In the context of financial crises, climate changes and social problems it is obvious that business should take responsibility for its activities which affect the society and the environment at large. It means a completely new business approach, intrinsically linked to the concept of sustainable development, which puts stakeholders' expectations at the heart of business strategy. One of the most famous definitions of CSR presents the document "Green Paper on Corporate Social Responsibility" developed by the European Commission (Green, 2001). In the light of this definition "being socially responsible" means not only fulfilling legal expectations, but also going beyond compliance. CSR encourages business to take responsibility for its operation in economic, social and environmental spheres. There is no clear-cut CSR definition, neither in subject literature, nor in practice. The majority of authors stress that in the face of global competition and rapid changes in business environment it is not possible to maintain competitive advantages without social responsibility implementation. However, the main aims of business activity are profitability and economic development, its impact on society and quality of life cannot be ignored.

The CSR strategy seen as a voluntary choice made by the management of corporation gives rise to the need of the disclosure of information about benefits and incurred costs during the implementation of this concept. Taking it into consideration, social accounting can be 
Anna WILDOWICZ-GIEGIEL. The Evolution and the New Frontiers of Social Responsibility Accounting

PROBLEMS

OF MANAGEMENT

IN THE $21^{\text {st }}$ CENTURY Vol. 9, No. 1, 2014

96

perceived as a product of the early social responsibility movement of the 1960s (Gray, Kouhy, Lavers, 1995; Mathwes, 1997; Medley, 1997). Along with that, the accountants started noticing the need for the application of double entry book-keeping to socio-economic analysis (Zaidi, 2012, p. 8).

There is a common consensus among scientists and practitioners, that effective presentation of activities identified with CSR is one of the necessary prerequisites for achieving advantages from being socially responsible. Social responsibility accounting as operational tool plays a particular role in the process of communicating the social and environmental effects of organizations' economic actions and requires the changes in accounting policy. For that reason the issue of the implementation of a new integrated model of reporting is the main subject of deliberations in this paper.

\section{The Concept and Functions of Social Responsibility Accounting}

CSR accounting is a process used to identify, measure, and present the state of CSR risk management and activities related to the improvement of CSR performance in monetary terms based on financial statements. Thanks to it both external and internal stakeholders can make assessments and decisions while having an awareness of phenomena identified with CSR issues as a risk. According to International Federation of Accountants which rather uses the term sustainable accounting, CSR accounting is applied to methodologies designed to financially quantify the impacts of enterprise activity on the natural environment and the social stakeholders' community. The majority of scholars perceive social accounting as a mechanism aimed at enhancing corporate accountability and transparency to a wide range of external stakeholders, addressing the environmental, social and ethical concerns and values of individuals upon whom a business has a non-economic impact (O’Dwyer, 2006, p. 220). It can be said, that CSR accounting embraces a part of accounting which tackles with the registration, analysis and reporting environmental and social effects of the influence of a given entity on its surrounding, as well as with the measurement of connections and interaction between economic, environmental and social issues which constitute three dimensions of sustainable development. One of the Polish researchers of this concept suggests social responsibility accounting focusing on: the identification of social costs and benefits which appear as a consequence of running a business, indicating the places of their generating and the ones which are responsible for it (Gabrusewicz, 2010, p. 60). To put it in a different way, social accounting concerns the collection, recording and evaluation of information on social and environmental performance of the company to particular interest groups within society and to society at large. Many authors describe social accounting as an extension of disclosure into non-traditional areas such as providing information about employees, products, community service or reduction of pollution. It allows enriching the information enclosed in traditional financial statement which is presented not only in a monetary but also in a descriptive form. Conversely to conventional method of accounting which measured the performances from the perspective of organization itself without trying to inform all the stakeholders about the externalities and the impact of the organization on the external environment, CSR accounting adopts here the completely different approach. To sum up, the main characteristic of CSR accounting can be summarized in the following three points (CSR, 2007, p. 12):

- a CSR accounting system is designed on the assumption that the majority of business activities are statistically measurable and expressed in some quantified form.

- CSR accounting focuses on the company's CSR management system and performs from a monetary perspective the identification and measurement of activities related to planning, implementation and management, monitoring, and revaluations. CSR accounting evaluates processes to determine whether the CSR management system operates effectively. What is more, it uses monitoring and feedback to improve management activities. From the perspective of managers, the gathered in- 
formation seems to be helpful in the minimization of CSR risk and the appropriate execution of business activities.

- the implementation of CSR accounting is treated as a tool that supports all kind of activities and efforts in the area of corporate social responsibility.

On the basis of the characteristic of CSR accounting discussed above, it is worth stressing, that social accounting can serve three main objectives. Firstly, it provides a complete picture of the organization and its resources. Secondly, this part of accounting system is perceived as an instrument the purpose of which is to prevent socially irresponsible behaviors. Finally, CSR accounting motivates and encourages companies to take up socially responsible activities (Krasodomska, 2013, p. 14). In conclusion, taking into consideration that social accounting consists of environmental, human resources and ethical accounting, each of these areas has its own major objectives. Environmental accounting focuses on the identification and measurement of the costs and the effects of the environment within the conservative accounting systems. As a part of the managerial accounting, it aims at developing new financial accounting and accountability systems performing the information and control functions in management. Human resources accounting concentrates on incorporating in the financial statements information regarding inputs and outputs which occur in the process of knowledge creation. The gathered information within this area refers to knowledge, competences, abilities, professional training, skills and talents in a given organization. In turn, ethical accounting comprises data concerning the organization's ethical values and behaviors in relation to consumers, business partners, natural environment and local community.

\section{The Business Benefits of Reporting on CSR}

CSR reporting is used by companies to measure, disclose, and be accountable to internal and external stakeholders with regard to their environmental, social, economic and organizational performance. These issues are presented within documents such as annual reports or sustainability reports. It is worth noticing, that this term can be regarded as synonymous with sustainability reporting. According to the most recent statistics, the number of global reports changed from almost zero in 1992 to an expected 4000 in 2010 (von Wensen, Broer, Klein, Knopf, 2011, p. 22-23). The growing popularity of CSR reporting observed over the past two decades encouraged the author to analyze the main reasons for companies to disclose information on their sustainability performance. The study, carried by Klynveld Peat Marwick Goerdeler (KPMG) in 2010, indicates the most important reasons for the disclosure of information on CSR, such as (von Wensen, Broer, Klein, Knopf, 2011, p. 19):

- comply with regulations;

- account for sustainability performance and activities;

- improve internal processes to enhance sustainability performance;

- promote achievements in sustainability to stakeholders;

- engage with stakeholders about sustainability performance or to meet their expectations;

- demonstrate management of sustainable performance.

The similar reasons for reporting were also shown in the survey conducted by Boston College Center for Corporate Citizenship and Ernst\&Young LLP in 2013. Firstly, it turns out that more than $50 \%$ of respondents stated that sustainability reports help to improve firm reputation and consumer loyalty. It is in accordance with the opinion of many researchers, who have claimed a key role of CSR reporting is to legitimize the actions of the company, what makes the corporate vision and strategy more credible. Information about corporate social and ecological expenses causes that consumers, who appreciate mitigate externalities, are willing to pay more for a product or service of the company. Secondly, CSR reporting contributes to the increase in the loyalty amongst employees. It is a tool of communication with them by which the comprehensive presentation of information on the incurred expenditure and the obtained results in the 
Anna WILDOWICZ-GIEGIEL. The Evolution and the New Frontiers of Social Responsibility Accounting

PROBLEMS

OF MANAGEMENT

IN THE $21^{\text {st }}$ CENTURY Vol. 9, No. 1, 2014

98

area of CSR is possible. This information allows for better understanding of company's core values and connections between the undertaken activities and its economic performance. As a result of it, CSR reporting increases employees' confidence, improves internal cooperation and encourage them to innovation. From the point of view of managers, CSR reporting enhances efficiency of internal processes and production. In a 2012 global survey of sustainability reporting almost $88 \%$ respondents indicated that it helps with decision making process. CSR reports provide firms with knowledge necessary to reduce their use of natural resources, increase efficiency and improve their operational performance. It turns out that CSR reporting allows enterprises to avoid or mitigate environmental and social risks that might have material financial impacts on their business while delivering better environmental, social and economic value. Above $60 \%$ of sustainability managers claimed that risk management is one of the top three reasons for their companies' sustainability activities. CSR reporting is perceived by managers as the form of monitoring long-term risk and improving long-term risk management and what is more, helps the organization to take measures to increase long-term profitability (Value, 2013, p. 3). However, it cannot be forgotten that CSR reporting serves a broad range of stakeholders. Information about CSR performance affects equity pricing indirectly by reducing uncertainty and information asymmetry between investors and a given company. Many investors are interested in investing in companies that engage in social responsibility. Recent research found, that one of the most important benefits of CSR reporting is easier access to capital because of the greater awareness of external stakeholders about the undertaken activities for the idea of sustainable development.

\section{The Implications of CSR Idea on the Accounting}

The growing interest in CSR idea forced the need of the extension of the scope of information, which traditional accounting system delivers (Solomons, 1974; Guthrie, Parker, 1989; Unerman, O'Dwyer, 2007). The purpose of CSR accounting is to identify, collect and measure costs and effects ascribed to CSR activities in accordance with the existing conservative accounting practice. It is a huge challenge, particularly if the majority of social and ecological accidents, which take part in an entity, cannot be understood as business operations from the point of view of accounting standards (Adams, 2002; Adams, Frost, 2007). Moreover, it is worth stressing, that traditional financial reporting, which focuses primarily on business activities, does not report much CSR-related information and is limited in terms of its role as a system of information disclosure and in aiding internal information management (Bebbington, Gray, 2001). However, not only professional and regulatory bodies but also academics are conscious about the rapid erosion of relevance of published earnings information. It can be confirmed by the increasing gap between market value and book value which have been observed since 1980s. In the face of growing importance of intangibles which are the major value drivers in the knowledge economy, the existing measuring conventions, including historical cost accounting seem not to be very useful in case of the need to disclose additional information related to intellectual capital and CSR. It is commonly known that the International Accounting Standard (IAS 38) criteria devoted to intangibles are very restrictive. The uncertainty regarding future benefits from intangibles, their uniqueness in certain occasions and the importance of reliability over relevance in current accounting systems narrows the list of items that are recognized as intangible assets. As a result, the traditional financial reporting framework presents an incomplete picture of a firm's value. Investors complain about today's financial reporting requirements because: they neglect to make connection between company's strategy and significant short- and long-term risk and opportunities, ignore significant sustainability challenges and opportunities facing companies, which may cause serious financial repercussions, tend to focus on past, short-term performance and omit significant liabilities that are contingent and difficult to quantify (Integrated, 2013, p. 1-2). Taking into consideration the broader group of stakeholders who are interested in the overall business activities and its potential impact on society and 
environment, it seems to be obvious that CSR issues cannot be ignored in the contemporary accounting system.

The design of CSR accounting framework is supposed to assure the identification and measurement of CSR activities in quantitative terms which can additionally be supplemented by nonfinancial indicators related to social, ethical and ecological issues (O'Dwyer, Owen, 2005). That is why, these CSR accounting guidelines should be constructed with the emphasis on the following three points (CSR, 2007, p. 19-20):

- identification - company management structure must recognize CSR issues as "risks" that have a major impact on corporate value.

- measurement- improvement in the reliability and transparency of financial data requires from managers to extend its scope and also to prepare descriptive information (Kaplan and Norton, 1996). In order to achieve it, the implementation of new measurement tools in accounting seems to be inevitable. They can be useful for efficient management of social and environmental risk, enabling the company to have a more holistic approach to sustainable development, measuring process and defining the strategy and targets for improvement. What is more, it is worth stressing that providing accurate and transparent information is a crucial key to build good relations with external stakeholders, in particular investors.

- present and evaluation - it is important to analyze and evaluate all kind of obtained information, coming from both CSR accounting system and financial accounting. Taking into account social and ecological effects triggered by the company, not only the changes in calculation forms but also a different, holistic approach to accounting system is needed.

It is worth underlying, that the key issue facing CSR accounting is how to adopt or rearrange the existing costs and calculation results. Because of mutual permeation of information produced by management accounting, the convergence between management and financial accounting is suggested (Samelak, 2013, p. 110-111). Apart from that, the presented in financial statements information on economic, social and ecological performance is supposed to be useful for the evaluation of the effectiveness of the management, as well as serve for prognostic purposes.

\section{Integrated Reporting as a New Model for Corporate Reporting}

The lack of uniform, global, financial reporting standards causes many implications which appear as a consequence of their inconsistency, incomparability or poor understanding of information coherence, complexity and mistrust towards drafted reports. Integrated reporting, as the latest evolution of corporate reporting, gives the real chance to avoid these problems and helps fill the information gap by providing a basis for companies to explain their value creation more effectively to the capital markets. In September 2011, the International Integrated Reporting Council (IIRC) as a global organization, consisting of accountancy bodies, reporting standard setters, investors and etc., prepared a discussion paper "Towards Integrated Reporting". The main objective of this organization is to establish guiding principles and to create globally accepted integrated reporting framework (Monterio, 2013, p. 7-8). Integrated reporting is a holistic approach to enable stakeholders to understand how an organization is really performing. According to IIRC, integrated reporting brings together the material information about an organization's strategy, governance, performance and prospects in the way that reflects the economic, social and environmental context within which it operates (Integrated, 2012, p. 128). To put it in a different way, integrated reporting seeks to communicate how an organization's business model affects the multiple resources and relationships which are used by company to create value in the short-, medium-, and long-term. 
PROBLEMS

OF MANAGEMENT

IN THE $21^{\text {st }}$ CENTURY Vol. 9, No. 1, 2014

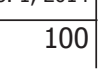

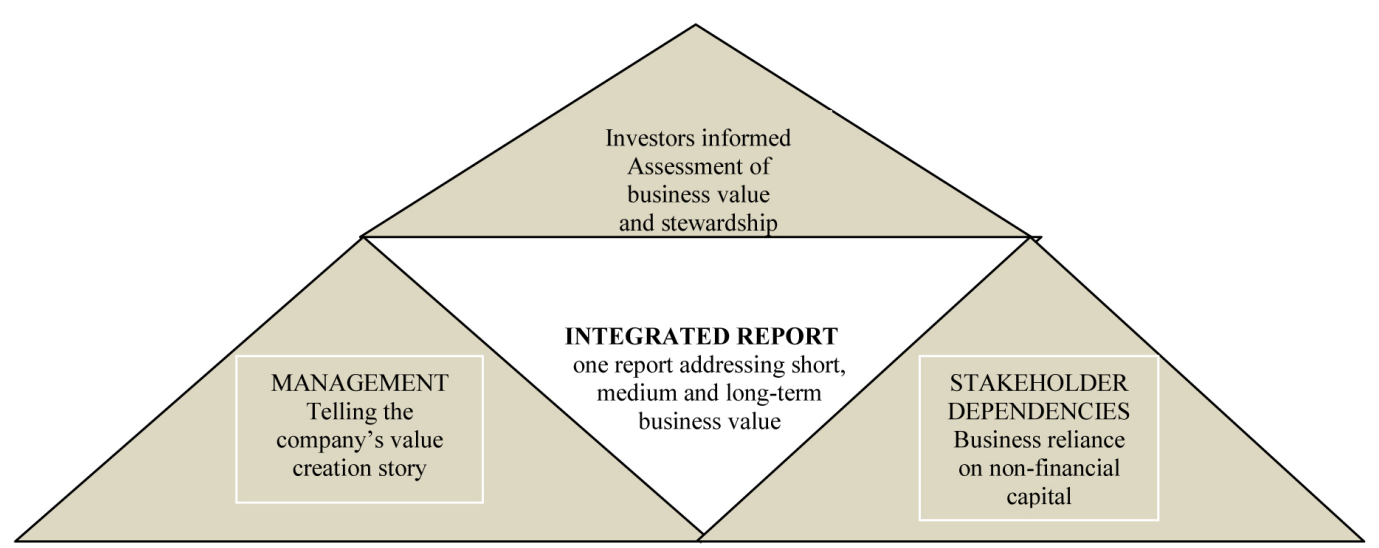

Figure 1: Bridging the three perspectives on business performance and value together.

Source: Integrated, 2013, p.7.

It is worth indicating the main objectives of integrated reporting. Firstly, it supports the information needs of long-term investors, showing the broader and longer-term consequences of decision-making. Secondly, it shows the interconnections between environmental, social and economic factors, not only making clear the link between sustainability and economic value but also enabling decision-making. Thirdly, this way of reporting provides the necessary framework for social and environmental factors to be taken into account systematically in reporting. Integrated reports allow better explain the process of value creation in the broader socio-economic context, focusing on the quality of relationship between a given entity and its external business environment. Finally, by a properly designed set of performance measures, the report is intended to increase the understanding of the company, its management, strategy, operations and prospects (Integrated, 2011, p. 1-2). Collecting within the report data about strategy, risk and opportunities, environmental and societal impacts is particularly important for managers and investors and contributes to more efficient resource allocation. In order to ensure the best quality of information included in reports, the IIRC prepared several principles on which integrated reporting should be underpinned. The most important among them are such as: strategic focus, materiality and conciseness, stakeholder responsiveness, information coherence, comparability, reliability and completeness (Monterio, 2013, p. 9). In spite of the continuing debate on integrated reporting, a globally accepted solution has not been found yet.

\section{Conclusions}

Along with the growing popularity of social responsibility, there is an urgent need to incorporate the CSR policies in the accounting records. The majority of initiatives undertaken in the social, environmental and ethical areas can be attributed to intangibles. However, the issue of measuring, evaluating and presenting this data in financial statements in accordance with restrictive accounting principles causes many problems. Apart from that, the further changes within accounting system should be introduced because of the increasing gap between data being reported by companies and the stakeholders' requirements. As people are more and more aware of business impact on the natural environment and the whole society companies must improve their communications with key stakeholders. A strong social and investor's pressure on companies to disclose their performance, including social and environmental aspects means a general shift from traditional reporting to integrated reporting. In this context social responsibility accounting and its product in the form of integrated reporting are perceived as the next stage of accounting development. 
On the basis of the conducted analysis it can be said, that CSR accounting as a communication tool, is addressed to the internal and external stakeholders. It allows the companies to have a more systematic approach to sustainable development, measure processes and define the strategy and targets for improvement. Thanks to transparent and accurate information on company's performance CSR reports provide benefits, such as attracting new investors, building public relations and enhancing competitiveness. They can contribute to the efficient social and environmental risk management and additionally enhance overall business effectiveness. Unfortunately, in spite of many guidelines on good practice in integrated reporting, a globally accepted framework that brings together financial, environmental, social and governance information in a clear, concise, consistent and comparable format has not been created yet. That is why the debate on integrated reporting is still being continued by many international organizations such as the International Integrated Reporting Committee (IIRC) involved in works on creating guiding principles and standardizing reporting framework.

\section{References}

Adams, C. A. (2002). Internal organisational factors influencing corporate social and ethical reporting: Beyond current theorising. Accounting, Auditing and Accountability Journal, 15 (2), 223-250.

Adams, C. A., \& Frost, G. R. (2007). Managing social and environmental performance: Do companies have adequate information? Australian Accounting Review, 17 (3), 2-11.

Bebbington, J., \& Gray, R. (2001). An account of sustainability: Failure, success and a reconceptualization. Critical Perspectives on Accounting, 12 (5), 557-588.

CSR Accounting Guidelines (2007). Kashiwa: Reitaku University Business Ethics \&Compliance Research, 18-19.

Gabrusewicz, T. (2010). Rachunkowość odpowiedzialności społecznej w kształtowaniu zasad nadzoru korporacyjnego. Warszawa: Wydawnictwo C.H.Beck, 56.

Green Paper. Promoting an European Framework for Corporate Social Responsibility (2001). Brussels: European Commission.

Gray, R. (2002). The social accounting project and accounting organizations and society: Privileging engagement, imagination. New accountings and pragmatism over critique? Accounting, Organizations and Society, 27 (7), 687-708.

Gray, R., Kouhy, R., \& Lavers, S. (1995). Corporate social and environmental reporting: A review of the literature and a longitudinal study of UK disclosure. Accounting, Auditing and Accountability, 8 (2), 47-77.

Guthrie, J., \& Parker, L. D. (1989). Corporate social reporting: A rebuttal of legitimacy theory. Accounting and Business Research, 19 (76), 343-352.

Integrated Financial and Sustainability Reporting in the United States (2013). New York: IRRC Institute, 1.

Integrated reporting. Performance insight through Better Business Reporting (2013). Issue 2, KPMG, 4-7.

Integrated Reporting (2011). Brussels: Federation of European Accountants, 1-2.

Integrated Reporting: The New Big Picture (2012). Deloitte Review, 10, 125-129.

Integrated Reporting and The Emerging Role of Internal Auditing (2013). Altamonte Springs: The Institute of Internal Auditors, 5-7.

Kaplan, R. S., \& Norton, D. P. (1996). Balanced scorecard. Translating strategy into action. Cambridge: President and Fellows of Harvard College.

Krasodomska, J. (2013). Corporate social responsibility as a factor influencing the development of social accounting and assessment of employees. e-Finanse. Financial Internet Quaretly, 9 (1), 12-25.

Mathews, M. R. (1997). Twenty-five years of social and environmental accounting research. Accounting, Auditing and Accountability, 10 (4), 481-531.

Medley, P. (1997). Environmental accounting - What does it mean to professional accountants? Accounting, Auditing and Accountability, 10 (4), 594-600.

Monterio, B. J. (2013). Corporate reporting evolved. Integrated Reporting and the Role of XBRL. XBRL International Inc., 6-9. 
Anna WILDOWICZ-GIEGIEL. The Evolution and the New Frontiers of Social Responsibility Accounting

PROBLEMS

OF MANAGEMENT

IN THE $21^{\text {st }}$ CENTURY
Vol. 9, No. 1, 2014

102

O'Dwyer, B. (2006). Theoretical and practical contributions of social accounting to corporate social responsibility. In: Allouche, J. (Ed.), Corporate Social Responsibility. Concepts, Accountability and Reporting. Volume 1, New York: Palgrave Macmillan, 233.

O’Dwyer, B., \& Owen, D. L. (2005). Assurance statement practice in environmental. Social and sustainability reporting. British Accounting Review, 37 (2), 205-229.

O'Dwyer, B., Unerman, J., \& Bradley, J. (2005). Perceptions on the emergence and future development of corporate social disclosure in Ireland: Engaging the voices of non-governmental organisations. Accounting, Auditing and Accountability Journal, 18 (1), 14-43.

Samelak, J. (2013). Zintegrowane sprawozdanie przedsiębiorstwa społecznie odpowiedzialnego. Poznań: Wydawnictwo Uniwersytetu Ekonomicznego w Poznaniu, 110-111.

Solomons, D. (1974). Corporate social performance: a new dimension in accounting reports? In: Edey, H. \& Yamey, B. S. (Eds.), Debits, Credits, Finance and Profits. London: Sweet \& Maxwell, 131141.

Unerman, J., \& O'Dwyer, B. (2007). The business case for regulation of corporate social responsibility and accountability. Accounting Forum, 31 (4), 332-353.

Value of sustainability reporting (2013). The Boston College Center for Corporate Citizenship and Ernst \& Young LLP, 3-5.

Van Wensen, K., Broer, W., Klein, J., \& Knopf, J. (2011). The state of play in sustainability reporting in the European Union. Brussels: European Union, 19.

Zaidi, M. (2012). Social accounting in India. Global Journal of Commerce \& Management Perspective, $1(1), 8-12$.

Advised by Camille Carbonnaux, University of Lille Nord de France, France

Received: January 31, 2014

Accepted: April 08, 2014

Anna Wildowicz-Giegiel

PhD., Assistant Professor, University of Bialystok, Warszawska 63,

15-062 Bialystok, Poland.

E-mail: awildowicz@interia.pl 